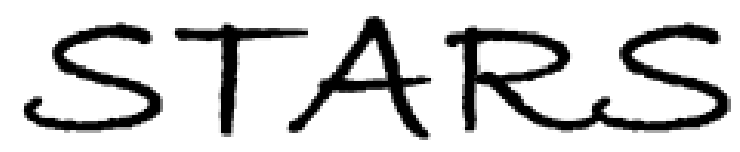

University of Central Florida

STARS

$1-1-2008$

\title{
Cognitive Development: Breast-Milk Benefit vs Infant Formula Hazard
}

Jerome L. Sullivan

University of Central Florida

Find similar works at: https://stars.library.ucf.edu/facultybib2000 University of Central Florida Libraries http://library.ucf.edu

This Article is brought to you for free and open access by the Faculty Bibliography at STARS. It has been accepted for inclusion in Faculty Bibliography 2000 s by an authorized administrator of STARS. For more information, please contact STARS@ucf.edu.

\section{Recommended Citation}

Sullivan, Jerome L., "Cognitive Development: Breast-Milk Benefit vs Infant Formula Hazard" (2008).

Faculty Bibliography 2000s. 1026.

https://stars.library.ucf.edu/facultybib2000/1026

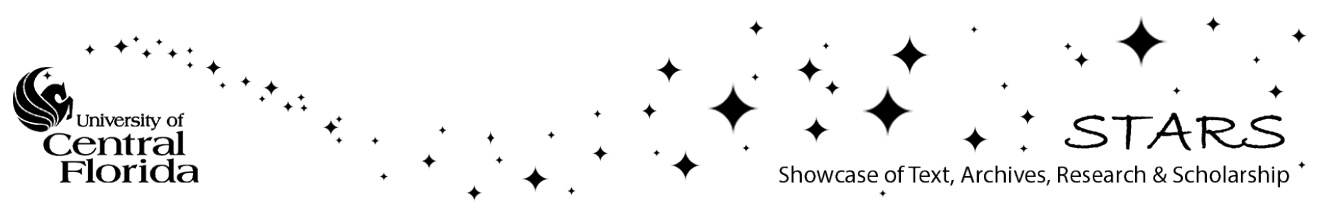


Cognitive Development: Breast-Milk Benefit vs Infant Formula Hazard

K ramer et $\mathrm{al}^{1}$ present evidence that breastfeeding improves children's cognitive development. They discuss 2 classes of explanation for their findings, noting that the superior cognitive development of breastfed children may be due either "to some constituent of breast milk" that promotes improved development or "to the physical and social interactions inherent in breastfeeding." (p582)

There is a third class of possible explanations not addressed in the discussion. Some property of infant formula may diminish developmental potential. This alternative explanation raises the possibility that breastfed children represent a normal reference population and that formula-fed children are harmed in some way in comparison with the breastfed group. The findings appear equally compatible with either an improved outcome from breastfeeding or, alternatively, a deficit conferred by some property of infant formula.

One candidate mechanism of harm in formula-fed infants is iron-mediated subclinical brain injury. Formula may increase infant exposure to non-protein-bound iron. Apolactoferrin derived from breast milk may protect infants from early iron-mediated brain injury that would otherwise impair later neurodevelopment. A general protective effect of apolactoferrin of maternal origin was previously proposed. ${ }^{2}$ It was suggested that "apolactoferrin may be absorbed from [breast] milk in amounts sufficient to boost plasma antioxidant activity." ${ }^{2(\mathrm{p} 1344)}$ Subsequent investigations have provided evidence that ironmediated free radical formation is involved in brain damage in neonates ${ }^{3}$ and that non-protein bound iron is a highly significant early predictor of later neurodevelopmental outcomes. ${ }^{4}$ It has been shown that recombinant human lactoferrin added to formula or human milk attenuates, and iron present in infant formula increases, iron-mediated free radical formation and lipid peroxidation. ${ }^{5}$ There is direct evidence of an antioxidant action of human milk. ${ }^{6}$

Jerome L. Sullivan, MD, PhD

Correspondence: Dr Sullivan, Burnett School of Biomedical Sciences, University of Central Florida, 4475 Old Bear Run, Winter Park, FL 32792 (jlsullivan3@gmail .com).

Financial Disclosure: None reported.

1. Kramer MS, Aboud F, Mironova E, Vanilovich I, Platt RW, Matush L, Igumnov S, Fombonne E, Bogdanovich N, Ducruet T, Collet JP, Chalmers B, Hodnett E, Davidovsky S, Skugarevsky O, Trofimovich O, Kozlova L, Shapiro S;
Promotion of Breastfeeding Intervention Trial (PROBIT) Study Group. Breastfeeding and child cognitive development: new evidence from a large randomized trial. Arch Gen Psychiatry. 2008;65(5):578-584.

2. Sullivan JL. Iron, plasma antioxidants, and the oxygen radical disease of prematurity. Am J Dis Child. 1988;142(12):1341-1344.

3. Buonocore $G$, Perrone $S$, Bracci R. Free radicals and brain damage in the newborn. Biol Neonate. 2001;79(3-4):180-186.

4. Buonocore G, Perrone S, Longini M, Paffetti P, Vezzosi P, Gatti MG, Bracci R. Non protein bound iron as early predictive marker of neonatal brain damage. Brain. 2003;126(pt 5):1224-1230.

5. Raghuveer TS, McGuire EM, Martin SM, Wagner BA, Rebouché CJ, Buettner GR, Widness JA. Lactoferrin in the preterm infants' diet attenuates ironinduced oxidation products. Pediatr Res. 2002;52(6):964-972.

6. Shoji H, Shimizu T, Shinohara K, Oguchi S, Shiga S, Yamashiro Y. Suppressive effects of breast milk on oxidative DNA damage in very low birthweight infants. Arch Dis Child Fetal Neonatal Ed. 2004:89(2):F136-F138.

\section{Results From the PROBIT Breastfeeding Trial May Have Been Overinterpreted}

$\mathrm{T}$ he Promotion of Breastfeeding Intervention Trial (PROBIT) study of infant feeding and childhood $\mathrm{IQ}^{1}$ is impressive, not least because it brings the benefits of randomization to an area where it was not previously thought feasible or even ethical. However, it may not be the last word on breastfeeding and IQ.

The headline result is a difference in verbal IQ between the experimental and control groups of 7.5 points. This is half a standard deviation and, therefore, a very substantial effect. But is it plausible? We believe it is not.

First, it is not supported by the other effects, which are all much smaller and have confidence intervals that include zero (ie, no impact). It is not even consistent with the other measures of verbal ability. The difference in verbal IQ estimated from the audit (quality control) sample is only 2.8 , less than a fifth of a standard deviation, and the difference in teacher ratings for reading and writing are both around a 10th of a standard deviation. In all 3 cases, the confidence intervals include zero. In short, the study as a whole gives little support for an effect of breastfeeding.

Second, there could be an important effect of language. The IQ test was administered in Russian, but for some children, Russian was not their first language. Some spoke Belarusian at home and others, Polish. Moreover, a large proportion of these children will have been of preschool age (preschool children being the largest component of the difference in sample size between the main results and the teacher ratings). The validity of a verbal IQ test administered in a second language to preschool children is questionable at best.

Third, the effect of language may have compounded problems with bias. Those administering the test could have made differential allowance for Russian not being the first language. It is worth recalling that the main assessments were not blind; the assessors were the same pediatricians who delivered the intervention. The audit 